\title{
サメの分類と生態
}

\section{谷内 透}

\begin{abstract}
巨大なサメに襲われるシーンはしばしば映画の題材となる. しかしすべてのサメがこのような挙動をす ることはない，長大な生物進化史のなかで，種分化のほとんど認められないものと，また種分化がよく 進んでいるものがあることは，海洋の環境がいかに多様であるかを示しているのではないだろうか.
\end{abstract}

サメの語源は狭眼であるといわれる(1). 漢字で は鮫と書き，体をくねくね動かして泳ぐ様に由来 する、しかし，サメは交尾をして内部受精をする から，鮫は交わる，すなわち“交尾をする魚”と 意訳することも可能であろら (2). 主に西日本でサ メを指すフカという言葉は鱆と書くが, 多くのサ メが胎生であることを考劣ると，まことに当を得 た表現ということになる．このように，漢字の意 味からもサメの様々な生態の一端をらかがい知る ことができよう。

さて，サメは分類上はふつらの魚が属する硬骨 魚綱とは大いに異なり，ギンザメ類（全頭业綱） とともに軟骨魚綱を形成し，エイ類とともに板鰓 亜綱を構成する. 軟骨魚綱の特徵を一口でいえ ば，その名の通り骨格が軟骨性であるといらこと であるが，このほかにもいろいろな特徴をそなえ ている、たとえば，らきぶくろがない，少なくと も胎仔の時代にサメ肌の元凶である楯鱗がある, らせん弁をもつ腸がある, 交尾器があり受精はす ベて体内で行なわれる，尿素やトリメチルアミン オキサイドを多量に含み浸透圧の調節に 役立て る，などの生理的生態的な特色を有している. 硬 骨魚綱とはこのような特徵で区別されるから，そ の違いは哺乳類と両生類の違いよりも大きいとす る説もある(3). また，一般に考えられている推測 とは逆に，硬骨魚が軟骨魚の祖先とする考えもあ $ろ^{(4)}$.

ところで, サメは同じ軟骨魚の中でもギンザメ

\footnotetext{
* Toru TANIUCHI, 東京大学農学部
}

類とは系統的には遠い関係にある．外見上も，ギ ソザメ類は外鰓孔が 1 つかないのに対し，サ メ・エイ類は $5 \sim 7$ 対の鰓孔をもつ(5). しかし， 同じ板鰓類のエイとの区別は必ずしも簡単ではな い.一般に，エイ類は体が平べったく，サメ類は 流線形をしていると考光れば間違いはないが，両 者の中間形をしたものもいる．両者の決定的な違 いは，サメの鰓孔はその一部分が少なくとも体側 に開いているのに対し，エイの鰓孔は腹面にある ということである(5).

\section{サメの 分 類}

サメの生態を明らかにするために，まずサメの 分類について触れておこう. 現在, 板鰓類の分類 についてはいろいろな考方方がある.サメ目とエ イ目に大別する考觉 ${ }^{(5)}$ は衰退し, カグラザメ目，ネ コザメ目，ネズミザメ目，ツノザメ目およびェイ 目の 5 つに分ける考觉 ${ }^{(6)}$ ，またカグラザメ目，ツ ノザメ目，ノコギリザメ目，カスザメ目，ネズミ ザメ目，メジロザメ目，テンジクザメ目，ネコザ ×目のサメ類 8 目, トビエイ目, サカタザメ目, ガンギェイ目，ノコギリエイ目，シビレエイ目の エイ類 5 目に分ける考党 などがある.

現在のサメの種類数は世界に約 350 種 ${ }^{(8)}$, 日本 近海に約 100 種が分布する(6). 表 1 に Cadenat et Blache ${ }^{(9)}$, Compagno ${ }^{(8)}$, 日本魚類学会 ${ }^{(6)}$ のも のに私見を加えた科ごとの種類数を示した。まず 目につくことは，オキシノータス科を除くラブカ 科，カグラザメ科，オナガザメ科，ウバザメ科， 
表 1 サメの科名と種 類 数

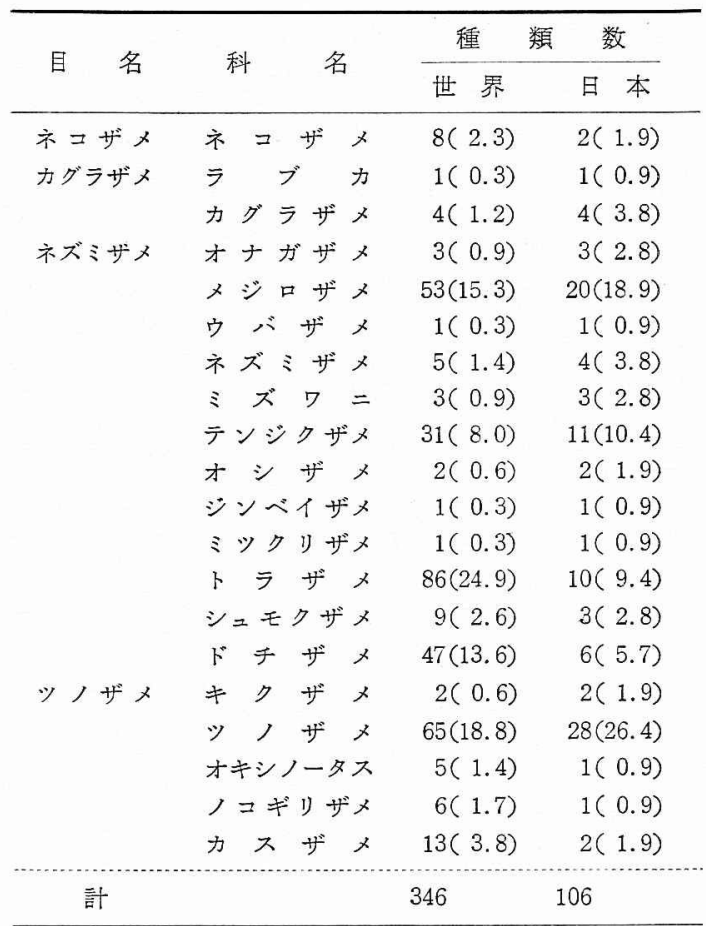

（）内は百分率を表わす。配列之目名は “日本産魚名大辞 典(6)”汇従う。

ミズワニ科，ネズミザメ科，オシザィ科，ジンベ イザメ科，ミックリザメ科など種類数の少ない科 のサメはそのほとんどが日本近海に分布するとい うことである。このことは，これらのサィがほと んど種分化せずに昔ながらの姿や形を留めている ことを物語っており，形態的にも珍しいものが多 い、また，そのほとえどが $3 \mathrm{~m}$ を超す大型種で （図 1)，外洋や深海などの比較的環境が安定した 所で生活する，たと党ば，ジンベイザメやウバザ メは全長 $10 \mathrm{~m}$ を超す大型種であり ${ }^{(10)}$ ，ラブカや ミックリザメは水深数百 $\mathrm{m}$ の深海域で生活す る(10).このように, 大きな体と外洋や深海に扝け る生活がこれらのサィをコスモポリタンに仕上げ たのであろら．

一方，メジロザメ科，テンジクザメ科，トラザ メ科，ドチザメ科，ツノザメ科，カスザメ科など は種類数がきわめて多く、また世界に分布する種 に較べて日本産がきわわて少ないのが特徴であ る。このうちのトラザメ科, ドチザメ科, メジロ ザメ科の 3 科に，オシザメ科とシニモクザメ科の

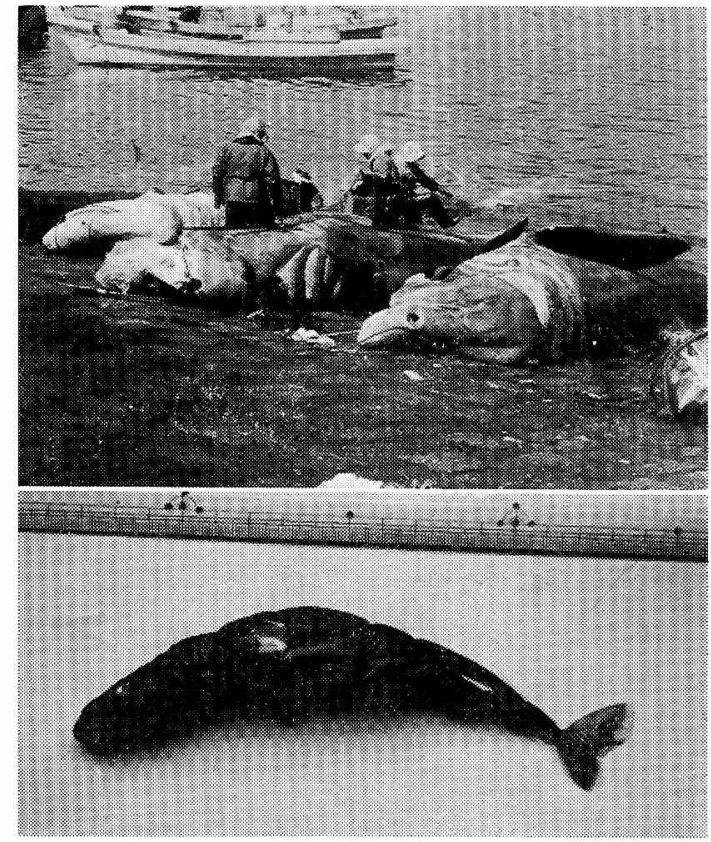

図 1 サメの大型種と小型種

上はウバザメ，全長 $10 \mathrm{~m}$ を超す. 下はオオメコビト ザメ，全長 $25 \mathrm{~cm}$ にしかならない。

2 科を加えてメジロザメ目とする考学(7) に従え ば，この目がサメ類の半分以上の種を占めること になる．このグループの種分化がいが著しいか がわかるであるう，一般に，進化の様式はトラザ メ科およびオシザメ科 $\rightarrow$ ゙゙チザメ科 科 シニモクザメ科と特殊化したと考兄られて いる.トラザメ科は全長 $1 \mathrm{~m}$ たらずの小型種が 多く, 亜寒帯や温帯の沿岸域あるいは深海を棲息 地としている. 移動力が小さいことと相まって， きわめて地域性が強い，ドチザメ科は餌の豊富な 温帯から 熱帯の 浅海域で 種分化を遂げたことか ら，トラザメ科同様，属数と種数の多いグループ である、メジロザメ科のサメは，もっともサメら しい流線形の体型をしており，体の大きなものが ほとんどで遊泳力が強い，乞の多くは食物環の頂 点に立つ. 中でも, メジロザメ属には 30 種が存 在し，その種の分化の著しさを端的に物語ってい る.

ツノザメ科はメジロザメ目のサメにより餌の豊 富な沿岸から条件の劣る深海域に追われたが(8), その深海で適応放散を行ない，様々な形態や生態 
を有するサメを生み出した，深海の生活に適応し て発光器をもつ種類もいる. テンジクザメ科は種 類数は多いものの, そのほとんどの種は太平洋・ インド洋域の浅海域に分布が局限され，特に オーストラリア沿岸に.多い.ネコザメ科も同様 で, 化石種は大西洋から見つかるものの，現生種 の分布は太平洋・インド洋域に限定され，しかも その生活場所は岩礁域に限られている. カスザメ 科は世界中に分布するが，1つ1つの種はきわめ て地域性が強く，進化からとり残されたグループ とい方よう. 以上の 4 つの科に属するサメは種類 数そのものは多いが，いずれも競争力の強いメジ ロザメ目のサメにより条件の悪い所での生活を強 いられ，種分化を遂げたグループといらことにな る.

谷内ら ${ }^{(11)}$ は, 分布パターンを外洋表中層性, 沿 岸表中層性, 沿岸底層性, 深海性の 4 つに区分し たが，一般にジンベイザメ科，オナガザメ科，ネ ズミザメ科，ミズワニ科，メジロザメ科，シュモ クザメ科，ドチザメ科の一部は外洋または沿岸の 表中層性，カスザメ科，ネコザメ科，テンジクザ メ科, ノコギリザメ科, トラザメ科の一部, ドチ ザメ科の大半のサメは沿岸底層性，カグラザメ 科，ラブカ科，ツノザメ科，キクザメ科，オキシ ノータス科, オシザメ科拈よびトラザメ科の多く の種は深海性といらことになる。

\section{サメの繁殖 様式}

サメの雄には腹びれの一部が变化した交尾器が あるので, 雌雄の区別は外部から容易に判別され る. 精巣から輸精管に排出された精子は交尾器を 通って雌の総排泄孔に入る. 受精は雌の卵款腺か 卵殻腺に近い輸卵管（通常サメでは子宮と呼ぶ） で生ずる。受精卵から発達した肧は母体から産み 出されるが，その時の胚の形態により, 卵生, 卵 胎生, 胎生などという用語がある.しかし, サメで 注卵生から胎生への变化が連続的なので, 最近は 卵胎生の用語は用いず，卵殸に包まれて産出され る様式を卵生, 親のミニチュアの子供が産み出さ れる様式を胎生と呼ぶ(12)。ここでは Wourms ${ }^{(13)}$, 手島敫に従って, サx類の生殖様式を考察し
よう.

口絵写真（p.447）(2)はラザメの卵款である. 受精後直ちに泼は卵殼に包まれ，母体外に産み出 される.トラザメ科のサメは，図のように四隅に 長いつるのような突起物があり，これで海藻など に絡みつく、ネコザメの卵殼はらせん状に凹凸が あり,トラザメ類の卵殼とはかなり形態を異にす る. 水温によって異なるが，胎仔が卵殼から外に 出るまでには約 1 年ほぞの時間がかかる．ふつ う， 1 つの卵殼内で 1 個の胎仔が成長するが，エ イの類では 2 個体が見つかることがある.ナガサ キトラザメでは，胎仔はふ化してから 6 〜 8 カ月 間体内に留まり，ある程度成長してから畉款に包 まれたまま母体から産み出される。

口絵(3はフトッノザメの胎仔である．胎盤を形 成しない典型的なサメの繁殖様式で，かつては卵 胎生と呼ばれていた．子宮内に胎仔の数と同じ数 の隔壁が生じ，胎仔膜に包まれて分婏時まで母体 内で成長する．自分の腹側にぶらさがる卵黄を主 に栄養源としている、ツノザメ科をはじめとする 多くのサメがこのような様式で繁殖する．ただ し，ラブカはある程度の大きさになると卵殼から 出て母体内で成長するので，この型と卵生との中 間型であるといえよう。

口絵(4)はネズミザメの胎仔である、卵巣から排 卵された卵のうち数尾だけが胎仔に発達する。多 くの場合，片側の子宮に 1 尾の胎仔がいるだけで あるが，時には 2 尾のことあある。初期には自己 の卵黄のらから栄養を補給するが，やがて排卵 される卵を栄養源として成長する，時には，ふ化 した胎仔を食べることも観察されている(15). 胎仔 の腹が食べた卵でふくらんでいるので胃卵黄とい う.この型の繁殖様式は共喰い型ともいえ, ネズ ミザメ科, オナガザメ科, ミズワニ科のサメがこ のようにして胎仔を成長させる．

口絵(5)ネムリブカの胎仔である．妊娠の中期 に胎仔の卵黄のう壁と親の子宮壁がつながり, 胎 盤を形成し, 以後, この胎盤を通して母体から栄 養が供給される。この様式のサメとしては，ドチ ザメ科の一部, メジロザメ科の多くの種, それに シュモクザメ科のサメが含まれる.シュモクザメ 
科の胎盤には“ほおずき”のような付属物が突出 し，呼吸の補助をしていると考えられている(16). トガリアンコウザメでは発生の初期に胎盤を形成 する(14). サメ類中もっとも進化した繁殖様式であ ろら.

このように, サメ類はきわめて特異な繁殖様式 を発展させてきた、長い進化の歴史（祖先型はお よそ 3 億年前のデボン紀に出現した $\left.{ }^{(17)}\right)$ を生き続 けたのも，このような繁殖方法を発達させてきた ためであろう．ただし，胎仔の数はきわめて少な く, 多い場合でもアメリカ産とオーストラリア産 のエイラクブカの平均 35 尾と 28 尾, あるいは ヨシキリザメの 26 尾, 少ない場合は胃卵黄型の 2 尾であるが，多くは平均 10 尾以下である(18). 妊娠期間は，多くは 10 力月から 1 年であるが, アブラッノザメでは 22 24 カ月の 妊娠期間を有 する. マグロ類のような大型硬骨魚が数百万粒の 卵を産むのとは異なり，親の保護がゆき届いてい るために胎仔の数は少なくてすむことになる.

\section{サメの食性}

サメ類が進化の歴史を生き抜いてきた他の要因 はその食性にあろう。サx類は一般に，肉食性の ぞう猛な生物として捉えられがちであるが，多様 な食物環境に応じて様々な食物摂取様式がある. サメ類の捕食様式を類別すれば(19)，かみつき型， 吸い込及型, 切断型, 飲久込及型, か及砕き型, ろ過型などに分けられよう。しかし，これらの様 式には厳密な区別をつけがたい。むしろ食性を区 分する上では，歯の形態から食物の摂取方法を論 じたほゔが説明がしやすいまた，歯は軟骨類の 化石として唯一の手がかりとなることが多く，分 類学上も重要な形質となっているので, ここでは 図 2 (次頁) を参考にして歯の形や機能に基づい て食性を分析することとしよう。

図 2 を見てもわかる通り，どのサメの歯も後方 に予備の 歯列が控えている. 図 2-1をを除けば, 最前列のせいぜい 2 列が直立するぐらいで，他は 後方にねている。ここでは，直立した歯を作用 歯, 予備の歯を未使用歯と呼ぶことにしょう。 つらは作用歯の後方に 6〜10 列注どの未使用歯
がありこれら未使用歯は顎の膜の上に載って前 方にせり出す仕掛けになっている. いわば，末使 用雪はベルトコンベアに載って口の前方にせり出 してくると思えばよい. 作用歯は未使用歯に押し 出されるようにして前方にずり落ちることにな る. 実験ではホシザメ類で約 10 日，レモンザメ では 8 日汇どで抜け落らる(20).

図2-1はホシザメの崡である. 毛歯状の歯が 舗道に敷きつめた石のように並んでいるのが特徵 である，見るからにかみつぶしに適した歯である ことがわかる. 実際, 硬い殼で被われたエビやカ ニなどをよく食べている(21).ヤドカリの出現率も 高いが，その宿貝は見つかっていない(21).この型 の歯はサメでは少数派であるが，エイではアカエ イ科を筆頭に多数派を形成する、ネコザメでは歯 の機能が分化し, 前方の歯は門歯状, 側方の歯は 臼歯状になっている(10).すなわち, 前方の歯で餌 を捕え, 後方の歯でこれをかみ砕くのに適した顎 をもつ. 捕食様式からみれば，かみつき型とかみ つぶし型の混合型といえよう.

図 2-2(2⿰フッノザメの歯である. 尖頭が極 端に傾いてほとんど横になり，隣接の歯とその根 元で接している.この型の歯は切断やえぐり取り に適しているといえよう．特にダルマザメの歯は その先端が鋭利になっていて，他の海産大型動物 の肉をえぐり取るのに便利な歯をしている。クジ ラ類や大型の魚類には，しばしばクレーター状の 傷口が見つかるが，ダルマザメにより肉をえぐら れた跡というのが通説である(10).ツノザメ科のサ メは上下の顎の一方，または両方にこのような歯 をもつものが多い，他の型の歯では, 最前列の歯 はばらばらに抜け落ちるが,この型の歯は 1 列が ほぼ同時に脱落し，新しい歯に変わる(20).

図2-(3はイタチザメの歯である。メジロザメ 科、シュモクザメ科の典型的な歯といえよう，歯 が三角形に近く，その縁辺が多くの場合ぎざぎざ になっているのが特徵である，この鋸状の縁辺が 慨にかみついたり，切断したりするのに役立つ. 人を襲らことで悪名高いホホジロザメも，この型 の歯をもつ，しかし，獲物をかみ切るというより は，むしろ丸飲みにすることが多い，大きな獲物 

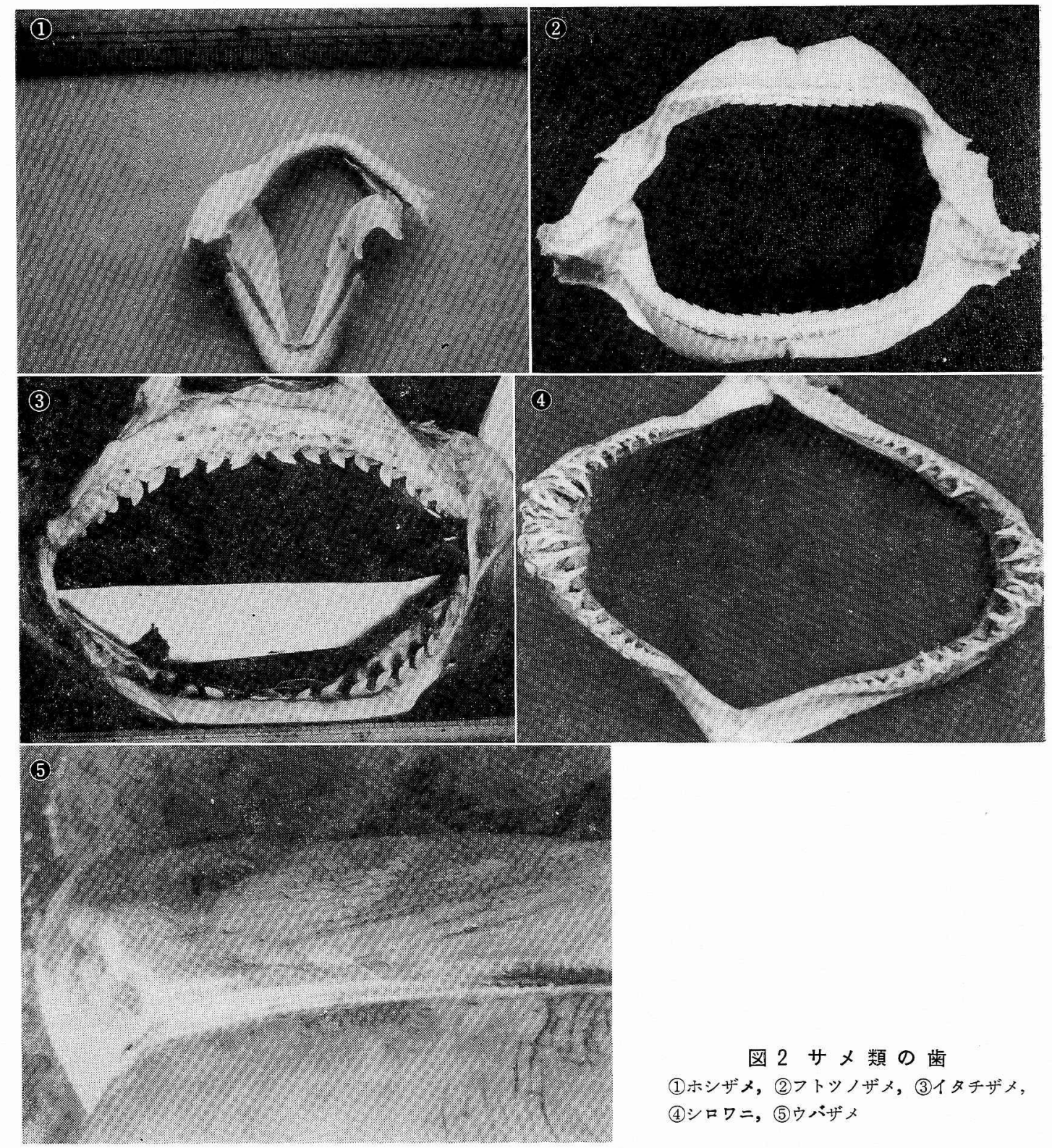

図 2 サメ類の歯

(1)ホシザメ，(2)フトッノザメ，(3)イタチザメ， (4)シロワニ, (5)ウバザメ

でもせいぜい 2 〜 個に切断して丸飲みにする. 胃袋を調べると，丸のままの魚が見つかることが 多小。

図 2-(4)はシロワニの歯である. 先がきりのよ らに尖った牙状の歯をもつ.イタチザメの歯とは 形が異なるが，獲物にかみつき，これを丸飲みに するという意味では捕食様式はほぼ同じと考えて よい、ネズミザメ科，ミズワニ科のサメがこの型 の歯を有する，丸飲み型の捕食様式をもつサメは
下顎を突出させて獲物を飲み込む(19).

図 2-(5)ウバザメの歯である. 眼の大きさに 較ベて歯がいかに小さいかがわかるであろら、ジ ンベイザメと並ぶプランクトンフィーダーで，鰓 の骨についた長い鰓耙で慨をこし取って食べる. ウバザメはプランクトンの少ない冬期には鰓耙が 抜汀て冬眠するといわれるが，これに疑問を呈す る意見もある(22).このほか，テンジクザィのよう に慨を吸い込んで捕食するサメもいる.

化学と生物 
文献

1）谷内 透: “䚗—The Sharks”, ダイビングワールド社, 1976 , p. 36 .

2）矢野害一：“鮫の世界”，新潮社，1976，p. 13 .

3) P.Budker: "The Life of Sharks", The World Naturalist, 1971, p. 8.

4) A. S. Romer: "Vertebrate Paleontology", Univ. Chicago Press, 1966, p. 38.

5）松原喜代松：“魚類の形態と検索”，石崎書店，1955, p. 99.

6）日本魚類学会(編)：“日本産魚名大辞典”, 三省堂，1981, p. 454.

7) L. J. V. Compagno: Am. Zool., 17, 321 (1977).

8) L. J. V. Compagno: Oceanus, 24(3), 5 (1982).

9) J. Cadenat \& J. Blache: "Requins de Méditerranée et d'Atlantique", ORSTOM, 1981, $330 \mathrm{pp.}$

10) J.I. Castro: "The Skarks of North American Waters", Texas A. \& M. Univ. Press, 1983, 180 pp.

11）谷内 透, 水江一弘, 田中 彰: ‘サx類の分布と移動”, “海洋の生物過程”，丸茂隆三編，恒星社厚生閣，1984，p.
186.

12）谷内 透，須山三千三(編)：“資源生物としてのサメ・エイ 類”, 恒星社厚生閣, 1984, p. 134

13) J. P. Wourms : Am.Zool., 17, 379 (1977).

14）千島和之：“生殖”，“資源生物としてのサメ・エイ類”，谷 内 透, 須山三千三編，恒星社厚生閣，1984，p. 60

15) A. J. Bass, J. D'aubrey \& N. Kistnasamy : Invest. Rep. Oceanogr. Res. Inst., 33, 15 (1975).

16) P. W. Gilbert: Oceanus, 24 (3), 39 (1982).

17) H. W. McCormick, T. Allen \& W. E. Young : "Shadows in the Sea", Chilton Books, 1964, p. 205.

18) 谷内 透: 海洋科学, 100,48 (1978)

19) S. A. Moss : Am. Zool., 17, 362 (1977).

20) P. W. Gilbert, R. H. Mathewson \& D. P. Rall : "Sharks, Skates and Rays”, John Hopkins Press, 1967, p. 319.

21）谷内 透, 黒田信久, 能勢幸雄: 日本水産学会誌, 49, 1332 (1983)

22) T. H. Lineawevwer III \& R. H. Backus : "The Natural History of Sharks", Lippincott, 1969, p. 123.

プロフィル

石 本 真 (Makoto Ishimoto) 大 正 14 年 2 月 12 日生 $<$ 略歴 $>$ 昭和 21 年東京 大学理学部化学科卒業 $/ 22$ 年同大学理学 部化学科助手 $/ 34$ 年同生物化学科助教授 $/ 42$ 年北海道大学薬学部教授, 現在にい たるく研究テーマと抱負〉婎気的呼吸, 硫黄代謝と生命の進化を結びつけて，生 化学的, 生態学的に研究してゆきたいく 趣味〉音楽（ルネサソス，バロックリ コーダー, ヴィオラダガソバ演奏）

乾博 (Hiroshi Inui) 昭和31年 3 月 9 日生<略歴>昭和53年大阪府立大学 農学部農芸化学科卒業 $/ 59$ 年同大学大学 院博士課程修了/同年学術振興会奖励研 究員, 現在にいたるく研究テーマと抱 負 >ミドリムシ (Euglena) のワックス・ エステル発酵の代謝機構, 特に酸素感受 性ピルビン酸脱水素酵素について. でき れば，Euglena の進化上の位置を明ら かにしたいく趣味〉読書

川内 浩司 (Hiroshi Kawauchi) Vol 20, No.6, p. 366 参照

川村美笑子 (Mieko Kawamura) 昭 和 24 年 3 月 5 日生<略歴>昭和 46 年高知 女子大学卒業 $/$ 同年同大学助手 $/ 52$ 年大
阪市立大学大学院前期博士課程進学 $/ 54$ 年同大学院修了/同年東北大学大学院後 期博士課程進学 $/ 56$ 年同大学院中退 /同 年同大学助手, 現在にいたる. 57年農博 〈研究テーマと抱負〉消化管の形態およ び機能に対する栄養条件の影響に関する 研究く趣味＞旅をすること，映画を観る こと，音楽を楽しむこと

北村 勲平 (Kumpei Kitamura) 昭 和15年 8 月 20 日生<略歷 $>$ 昭和 39 年京都 大学農学部農芸化学科卒業/同年キリン ビール(株)入社, 研究所勤務 $/ 57$ 年同社 開発科学研究所所長代理，現在にいたる <研究テーマと抱負〉幅広、徽生物の利 用に興味がある. 特に新規酵素, 有用物 質の探索く趣味 $>$ 渓流釣り，山歩き

木村 修一 (Shuichi Kimura) Vol 12, No.8, p. 531 参照

黒津 敏嗣 (Toshitsugu Kurotsu) 昭和 17 年 1 月 22 日生 $<$ 略歴>昭和 41 年京 都府立大学農学部農芸化学科卒業 $/ 46$ 年 京都大学理学研究科博士課程中退/同年 科学技術庁放射線医学総合研究所研究員 $/ 50$ 年兵庫医科大学生化学教室助手, 現 在にいたる.この間，56年西独ベルリン
工科大学研究員として留学く研究テーマ と抱負>抗生物質産生の調節に関する研 究および胞子形成期の細胞内プロテオリ シスとその調節機構の研究く趣味 > 音楽 鑑賞

桑本 融 (Tooru Kuwamoto) 昭 和 5 年 11 月 19 日生 $<$ 略歴 $>$ 昭和 28 年京都 大学理学部化学科卒業 $/ 36$ 年同大学理学 部助手, 理博 $/ 39$ 年同講師 $/ 40$ 年助教授, 現在にいたるく研究テーマと抱負〉海洋 における化学種の溶存状態, 気化性金属 キレートの分析化学

月向 邦彦 (Kunihiko Gekko) 昭 和 17 年 7 月 26 日生 <略歴>昭和 41 年広島 大学理学部化学科卒業 $/ 43$ 年同大学大学 院修士課程修了/同年愛知教育大学 勤 務 / 46年名古屋大学農学部食品工業化学 科助手, 現在にいたる. 46年理博（広島 大学).この間， 50 年より 2 年間米国 Brandeis大学留学〈研究テーマと抱負> 生体高分子の水和現象に興味を持ち，そ の構造安定性や機能との関係を明らかに しようとしているく趣味>クラシックギ ターと团碁 